shielding box. The impact of electric waves upon the receiver is indicated by the ringing of the bell. The radiator can be placed at different angular positions. With this apparatus are shown experiments illustrating the opacity of metallic screens, continuous or perforated to electric radiation; the transparency of insulating screens, and the transparency or opacity of various liquids. Water is found to be particularly opaque even in very thin layers. All damp objects are very impervious to this radiation, such as a wet duster, a moist brick, tobacco having more than the legal amount of water added to it, and the human body or hand. The refraction of electric wayes is shown by the use of a paraffin wax prism, the concentration by paraffin lenses, and the polarised quality of the rays by their reflection or stoppage by parallel wire gratings. Also the production of secondary oscillations in linear conductors by hulding rods of metal or tubes of liquid in the radiation. The wave length of the radiation is measured by producing interference as a result of splitting the beam into two portions and transmitting the two portions down two zinc tubes, the relative lengths of which can be adjusted.

Prof. A. C. Haddon, F.R.S., cinematograph photographs of native dances in Torres Straits.

\section{THE RE-ORGANISATION OF THE} EDUCATION DEPARTMENT.

$\mathrm{I}$ introducing the Secondary Education Bill to the House of Lords on Tuesday last, the Duke of Devonshire made the following remarks on the re-organisation of the Education Department :-

"Your lordships may remember that on the Bill of last year some discussion took place upon the future organisation of the Education Department. I thought at the time, and I am still more strongly of opinion now, that that discussion was somewhat premature. It proceeded on the assumption that the organisation of the new office would continue on the same lines as those which had existed when the educational departments were separate and distinct, and that there would be in the new office two divisions, one of which would carry on the work of the old Education Office in connection with elementary education, and the other of which would carry on the work of the Science and Art Department. . . . We now propose to revert to a dual organisation of the office, but not entirely upon the lines of the late Education and Science and Art Departments. The prin. cipal officers of the department which we propose will be a principal permanent secretary, who will supervise generally the whole work of the department. It must be remembered, when special importance is attached to this or that minor subordinate appointment, that it will be the permanent secretary who will be responsible to the President of the Board in the administration of the whole department, and that it is imposible, and would be undesirable if it were possible, that the office should be divided into what I may call water-tight compartments, the head of each of which would be charged with special duties and no other, and that the idea should be entertained that the work of the office should be carried on in several departments, which should have no connection or relation with each other. We propose that under the principal permanent secretary there shall be two principal assistant secretaries, one mainly charged with duties in connection with elementary and the other with secondary education. We propose to abolish the name 'Science and Art Department.' The Science and Art Department will be merged in the secondary education branch of the office. As soon as it may be possible, we propose to transfer the greater part of the staff of the late Science and Art Department from South Kensington to Whitehall, except such part of it as may be necessary to leave at South Kensington for the administration of the museum and the colleges of science and art. In place of the third division that was contemplated, we now propose to give the principal assistant secretary of secondary education two addi. tional assistant secretaries, one of whom will be chiefly charged with the supervision and control of literary instruction, and the other of technological study. This is not the organisation, I admit, to which I partly committed myself last year; but I trust that it may, in substance, meet the views, especially the later views, which have been expressed to me by high educational authorities. With the name we hope to get rid of many of the traditions which were sup. posed to attach to the old Science and Art Department-

NO. I 600 , VOL. 62$]$ traditions which have, I believe, been regarded as opposed to the true interests of education by many of those who have been responsible for the management of the older endowed schools. The original idea of the Science and Art Department was, or at all events was supposed to be, that by means of lectures, classes, and examinations a knowledge of the principles of science and art, which would be valuable to the students themselves and to the nation at large, could be engrafted upon almost any kind of previous elementary or secondary training. It is quite true that this idea has been in recent years very largely modified, but I do not think that it is yet generally known how far the original traditions of the Science and Art Department have been already departed from. We hope and intend that the idea of the future education branch of the office will be to make science and art instruction a part of general education in addition to those classical and literary studies which have hitherto formed its main portion. In the schools and institutions directly assisted by the Board of Education the teaching of science and of art, with the addition, perhaps, of some commercial subjects, will probably remain the principal object. But, on the other hand, in those secondary schools, whether of older or more modern type, which desire to enter into connection with the board, there ought not to be, and there need not be, any interference with the older classical and literary studies so long as there continues to be a demand for them. At the same time, we hope that the scientific resources of the Board will be placed at their disposal if they desire, as many of them do desire, to develop the more modern sides of instruction and education.... It may be of interest to the House to know what are the principal appointments which have been made or are proposed to be made in the principal office of the new secondary education branch of the department. Sir George Kekewich, the late secretary of the Board of Education, has.become the permanent principal secretary of the new Board, and it is he who will be responsible to the President of the Board and to the Government for the administration of the department as a whole. The principal assistant secretary for secondary education will be Sir William Abney, who has done more than any other man in extending the studies of the schools of science under the Science and Art Deptrtment. Under him the assistant secretary to deal with the literary side of instruction will be Mr. Bruce, an assistant commissioner to the Charity Commission under the Endowed Schools Act, who has been chiefly engaged and has obtained much experience in the administration of the Welsh Act. The assistant secretary for technological study has not yet been appointed."

\section{UNIVERSIT Y AND EDUCATIONAL INTELLIGENCE.}

CAMBRIDGE. - Prof. Sir Michael Foster has been nominated by the Council of the Senate as the representative of the University of Cambridge on the Council of the Jenner Institute of Preventive Medicine.

Mr. A. W. Hill, of King's College, and Mr. L. LewtonBrain, of St. John's College, have been appointed University Demonstrators in Botany.

Mr. E. E. Walker, Trinity College, has been elected to the Harkness Scholarship in Geology and Palæontology.

Prof. Woodhead announces ten courses of lectures and demonstrations in Pathology and Bacteriology to be held during the ensuing Long Vacation.

Mr. Shelfurd Bidwell, F.R.S., was on June 19 admitted to the degree of Doctor of Science.

Mr. W. N. Shaw, F.R.S., has been elected a Senior Fellow of Emmanuel College. It is a condition attaching to his tenure that he shall give annually in the University not less than three lectures on the Physics of the Atmosphere or some kindred subject. Mr. C. T. R. Wilson, F.R.S., formerly Clerk Maxwell Student in experimental physics, has been elected to a fellowship at Sidney Sussex College.

The following have been awarded scholarships or exhibitions in Natural Science at the several colleges at the end of the academical year :-

Clare College: Bailey, Cartwright, Cassidy, Hughes.

Pembroke College: Lang, Anderson, Hall.

King's College : Kewley, French, Wilde, Mollison, McIntyre. Christ's College: Fox, Moore, Wilson, Macnab, Muff, Cumberlidge, Sewell 